\section{Effects of Powdery Mildew of Grape on Carbon Assimilation Mechanisms of Potted 'Chardonnay' Grapevines}

\author{
William R. Nail and G. Stanley Howell \\ Department of Horticulture, Michigan State University, East Lansing, MI, 48824-1325
}

Additional index words. photosynthesis, stomatal conductance, Uncinula necator, chlorophyll fluorescence

\begin{abstract}
Potted grapevines (Vitis vinifera L. 'Chardonnay') were inoculated with conidial suspensions of the grapevine pathogen causing powdery mildew of grape (GPM) (Uncinula necator (Schw.) Burr.). Leaves of inoculated and noninoculated vines were studied for the effects of varying light $(P A R)$ and $\mathrm{CO}$, concentrations on factors affecting carbon assimilation. GPM reduced carboxylation efficiency $(k)$, net $\mathrm{CO}_{2}$ assimilation rate $(A)$, stomatal conductance $\left(g_{\mathrm{s}}\right)$, and internal $\mathrm{CO}_{2}$ concentration $\left(\mathrm{C}_{i}\right)$ under ambient $\mathrm{CO}_{2}, A_{\max }$ at $>900$ ppm $\mathrm{CO}_{2}$, stomatal limitations to $A\left(\mathrm{l}_{\mathrm{g}}\right)$, and photochemical efficiency $(\phi)$ on diseased leaves, while having no effect on the $\mathrm{CO}_{2}$ compensation point $(\Gamma)$ or the light compensation point (cp). GPM had no significant effect on chlorophyll fluorescence $\left(F_{v} / F_{m}\right)$.
\end{abstract}

Plant responses to foliar biotic and abiotic stresses may vary with the nature (causal element) and magnitude of the stress. Net $\mathrm{CO}_{2}$ assimilation $(\boldsymbol{A})$ by foliage is a critical factor influencing plant productivity, since $\geq 90 \%$ of plant dry matter is derived from C fixed through photosynthesis $\left(\mathrm{P}_{\mathrm{n}}\right)$ (Flore and Lakso, 1989). Therefore, factors that inhibit assimilation through $\mathrm{P}_{\mathrm{n}}$ may be detrimental to productivity.

Photosynthesis in plants can be limited by biotic stresses in a variety of ways. Johnson (1987) divided the seven categories of foliar pest effects on plants as described by Boote et al. (1983) into two groups: a) those whose major effects are on solar radiation interception (tissue consumers, leaf senescence accelerators, stand reducers, and light stealers) and b) those whose major effects are on relative use efficiency (photosynthetic rate reducers, assimilate sappers, and turgor reducers). Damage to the photosynthetic apparatus may occur by more than one of these effects; reductions in $A$ caused by the effects of most foliar pathogens on photosynthetic activity result from a decrease in the photosynthesizing leaf area and/or its reduced efficiency (Goodman et al., 1986; Shtienberg, 1992; Yarwood, 1967).

Response patterns affecting reductions in $\mathrm{P}_{\mathrm{n}}$ and transpiration $(E)$ have been related to the general type of trophic relationships involved (Shtienberg, 1992); powdery mildews tended to have more similar response patterns as compared to other foliar pathogens, for example. Powdery mildew of barley [Blumeria (syn. Erysiphe) graminis D.C. ex Merat f.sp. hordei Marchal] was associated with decreases in chlorophyll after $4 \mathrm{~d}$ of infection and loss of electron transport activity, with no loss of electron carrier concentration in remaining chlorophyll (Holloway et al., 1992). Powdery mildew of sugar beet (Erysiphe polygoni

Received for publication 30 June 2003. Accepted for publication 24 Nov. 2003. I thank James A. Flore and Adriana Nikoloudi for their technical assistance.
DC) infection was associated with inhibition of electron transport in noncyclic proteins, accompanied by alterations in chloroplast ultrastructure and reduction of enzyme activity (Magyrarosy et el., 1976). Carboxylation resistance increased in winter wheat infected by Blumeria (syn. Erysiphe) graminis D.C. ex Merat f.sp. tritici, with consequent negative effects on stomatal resistance, boundary layer resistance, and transport resistance (Rabbinge et al., 1985). Carbon assimilation was negatively affected by powdery mildews in all three studies. There does not appear to be a relationship between decreases in $A$ and $E$ among pathosystems; rather, $E$ has been shown to increase, decrease, or stay the same in response to foliar pathogens, including those causing powdery mildew symptoms (Shtienberg, 1992).

Grape leaves infected with Uncinula necator (Schw.) Burr. have demonstrated reduced photosynthetic rates compared to uninfected leaves (Lakso et al., 1982), due to destruction of palisade cells by the pathogen. Transpiration was not affected; consequently, water-use efficiency was less in infected leaves. Field experiments have demonstrated negative effects of GPM on grapevine health during the season of infection, including decreased fruit quality (Gadoury et al., 2001; Ough and Berg, 1979; Pool et al., 1984) and fruit set (Chellemi and Marois, 1992). Multiseasonal effects include reduced vine size (as determined by cane pruning weights) and yield in susceptible varieties (Pool et al., 1984), or only with vine size in relatively resistant varieties (Gadoury et al., 2001).

Defoliation experiments have been conducted on grapevines for a variety of reasons, including manipulation of fruit set, modifying the fruit microclimate, and to simulate pest damage. Grapevine responses to defoliation by removing whole leaves frequently include increased $A$ by the remaining leaves (CandolfiVasconcelos and Koblet, 1990, 1991; Hofäcker, 1978; Intrieri et al., 1997), although Candolfi-
Vasconcelos et al. (1994) found no increase in photosynthetic rate in the remaining leaves. Punching holes in the leaves of other crop species have been used to simulate the effects of damage by phytophagous arthropods (Boucher et al., 1987; Flore and Irwin, 1983; Poston et al., 1976). Stacey (1983) found that leaf removal on tomato plants largely approximated pest damage. Defoliation experiments have been inconsistent in approximating damage caused by foliar pathogens, as visual estimates of infection do not always adequately indicate the effects of a pathogen on photosynthetic and transpirational activities (Shtienberg, 1992).

Measurements of chlorophyll fluorescence have also been used to determine the health of photosynthetic mechanisms in plants (Buwalda and Noga, 1994; Krause and Weis, 1991) and have been correlated with end-product inhibition of leaf $A$ due to damage to photosystem II (PSII) (Layne and Flore, 1993). Damaged leaves may exhibit less potential maximal photochemical efficiency than uninfected leaves, depending on the nature of pathogen-induced foliar damage.

These experiments were designed to determine the physiological effects of GPM infection on individual grape leaves regarding gas exchange and chlorophyll fluorescence.

\section{Materials and Methods}

Plant material. Two-year-old dormant grapevines (V. vinifera L. 'Chardonnay', Dijon clone 96, grafted to Courdec 3309 rootstock) were planted in $19-\mathrm{L}$ pots in a medium of $50 \%$ loam, $40 \%$ sand, and $10 \%$ peat. The plants were grown and maintained on a gravel pad outdoors at the Horticultural Teaching and Research Center, Michigan State University, East Lansing, during the 2002 growing season. Plants were thinned shortly after full bud burst to three shoots per vine. Vines were watered regularly to container capacity and fertilized monthly with a soluble fertilizer at a rate of $0.38 \mathrm{~g} \mathrm{~N}, 0.17 \mathrm{~g} \mathrm{P}$, and $0.32 \mathrm{~g} \mathrm{~K}(1.9 \mathrm{~g}$ Peter's 20-20-20) per pot. Plants were largely fruitless; a few plants that did have fruit were retained to determine phenological stages during the growing season. Flower clusters were removed from all treatment plants prior to bloom. Laterals were removed as they appeared throughout the growing season. Two applications of Sevin [1-naphthyl N-methylcarbamate (carbaryl), Aventis, Bridgewater, N.J.] liquid were made as needed to control Japanese beetle (Popillia japonica Newman) infestations. All chemical applications were made at least $7 \mathrm{~d}$ before gas exchange measurements.

Experimental design. Plants were blocked according to the fresh weight of the dormant, unpotted vines and arranged in a randomized complete block design with 32 blocks. Treatments were assigned randomly within blocks and wereas follows.

1) Plants inoculated with a conidial suspension of $U$. necator in distilled water (produced by soaking infected leaves of Marechal Foch (Kuhlmann 188-2) grapevines for $\approx 10 \mathrm{~min}$ and agitating to dislodge conidia) between the 5 $\mathrm{mm}$ berry (as determined from the nontreat- 
ment fruited vines) and 1200 growing degree days (GDD) (base $10^{\circ} \mathrm{C}$ ) stages using a hand sprayer and sprayed to runoff(James Olmstead, personal communication). Concentrations of conidia in suspension were not determined. This treatment was designated "Infected."

2) Plants were sprayed with myclobutanil $[\alpha-$ butyl- $\alpha$-(4-chlorophenyl)- $1 H-1,2,4$, triazole1-propanenitrile (NOVA), Rohm and Haas, Philadelphia, Pa.] at bloom (16 June) and between the 5 -mm berry stage and midseason (23 July, $\approx 1200$ GDD) at a rate of $0.21 \mathrm{~g}$ myclobutanil/ $/ \mathrm{L} \mathrm{H}_{2} \mathrm{O}$ and sprayed to runoff. This treatment was designated "Noninfected".

Plants sprayed with myclobutanil were separated from inoculated plants by $\approx 10 \mathrm{~m}$ for $48 \mathrm{~h}$ to help eliminate the potential effects of drift and/or volatiles from affecting inoculated plants. Noninfected plants had levels of GPM $\leq 5 \%$ through the veraison period.

Ten plants from each treatment were selected for gas exchange responses to varying $\mathrm{CO}_{2}$ concentrations and photosynthetically active radiation $(P A R)$ level measurements by the following criteria: The most recent fully expanded leaves on the longest shoot on each plant were examined just before veraison; leaf health was evaluated based on visual ratings of disease severity, expressed as a percentage of the leaf surface with visible GPM infection. The most recent fully expanded leaves from each of the 10 blocks which had both the healthiest noninfected leaves and an obviously infected, but otherwise undamaged (by insects, wind laceration, etc.) leaf, were selected for gas exchange measurements. Disease severity on infected leaves ranged from $60 \%$ to $90 \%$ infected leaf area. Most $(>80 \%)$ leaves on infected vines had visible symptoms of GPM; overall disease severity was not assessed on a vine-by-vine basis, but was estimated to be $50 \%$ at the time of measurement. There were no visible disease symptoms on noninfected leaves. Plants selected for measurement were watered to pot runoff the previous day to ensure lack of water stress during measurements.

Gas exchangemeasurements. Gas exchange measurements were conducted using a portable infrared gas analyzer (IRGA) (CIRAS-2, PP Systems, Amesbury, Mass.) fitted with a leaf cuvette with light source (PLC6; PP Systems). Effects of $\mathrm{CO}_{2}$ concentration were determined by gradually increasing $\mathrm{CO}_{2}$ from 0 to $200 \mathrm{ppm}$ at 50-ppm increments, and from 200 to 1000 ppm at $100-$ ppm increments at $P A R=1500$, allowing the IRGA to equilibrate between each measurement using the onboard computer (PenCentra 130; Fujitsu PC Corp., Santa Clara, Calif.) and software (version 1.0, PP Systems, Amesbury, Mass.). Responses to changes in $P A R$ were taken immediately afterward, using the same equipment and software, by reducing PAR from 2000 to 200 in 200 PAR increments, and from 200 to 0 in 50 PAR increments. Measurements were taken between 0900 and 1500 $\mathrm{HR}$ at $26^{\circ} \mathrm{C}\left( \pm 2^{\circ} \mathrm{C}\right)$ air temperature. Plants were measured within each block according to their random placement to help alleviate the effects of natural diurnal variances in $A$ (Downton etal., 1987). The data were analyzed by applying the
Marquardt-Levenberg algorithm for nonlinear regression analysis for curve fitting (Layne and Flore, 1992, 1995; Marquardt, 1963).

Parameters calculated from plant responses of $A$ to variable $P A R$ (light response curves) were: the light compensation point (cp), extrapolated from the data where $A=0$, and quantum yield $(\phi)$, as determined by the slopes of the linear portion of the curves. Parameters calculated from plant responses of $A$ to variable internal $\mathrm{CO}_{2}$ concentration $\left(\mathrm{C}_{i}\right)$ were the $\mathrm{CO}_{2}$ compensation point $(\Gamma)$, extrapolated from the data where $A=0$; carboxylation efficiency $(k)$, as determined by the slopes of the linear portion of the curves; stomatal limitation to $A$ $\left(1_{\mathrm{g}},\right)$, calculated according to the differential method of Jones (1985); and $\mathrm{A}_{\max }$, the maximum $A$ value at saturating $\mathrm{CO}_{2} . A, g_{\mathrm{s}}$, and $\mathrm{C}_{i}$ at ambient $\mathrm{CO}_{2}$ concentrations and saturating light conditions were also measured $\left(A_{360}, g_{\mathrm{s} 360}\right.$, and $\mathrm{C}_{i 360}$, respectively).

Single leaf measurements were also performed on the most recent fully expanded leaf of the longest shoot on all plants in the plot over a period of $2 \mathrm{~d}$ to determine relationships, if any, between $A$ and $g_{\mathrm{s}}$ and $\mathrm{C}_{i}$, at $P A R=1000$ and $\mathrm{CO}_{2}=375 \mathrm{ppm}$.

Chlorophyll fluorescence measurements. Three blocks were randomly selected for chlorophyll fluorescence measurements. The longest shoot on each plant, also used for gas exchange measurements, was selected and each leaf evaluated for disease severity, expressed as the percentage of leaf area with visible GPM symptoms. A clip with a sliding window to admit or exclude light was attached to each leaf, and the leaf section was allowed to dark acclimate for $\geq 30 \mathrm{~min}$. Chlorophyll fluorescence was measured with a plant efficiency analyzer (model PEA; Hansatech Instruments, Norfolk, U.K.). Fluorescence was expressed as the ratio of variable fluorescence $\left(F_{v}\right)$ to the maximum fluorescence $\left(\mathrm{F}_{\mathrm{m}}\right)\left(\mathrm{F}_{\mathrm{v}} / \mathrm{F}_{\mathrm{m}}\right)$.

Destructive harvest measurements. Plants from all 32 blocks were destructively harvested after leaf fall and cut into component plant parts (roots, trunk, shoots, and leaves), and fresh weights were measured. These plant parts were dried in a forced-air drying oven at 45
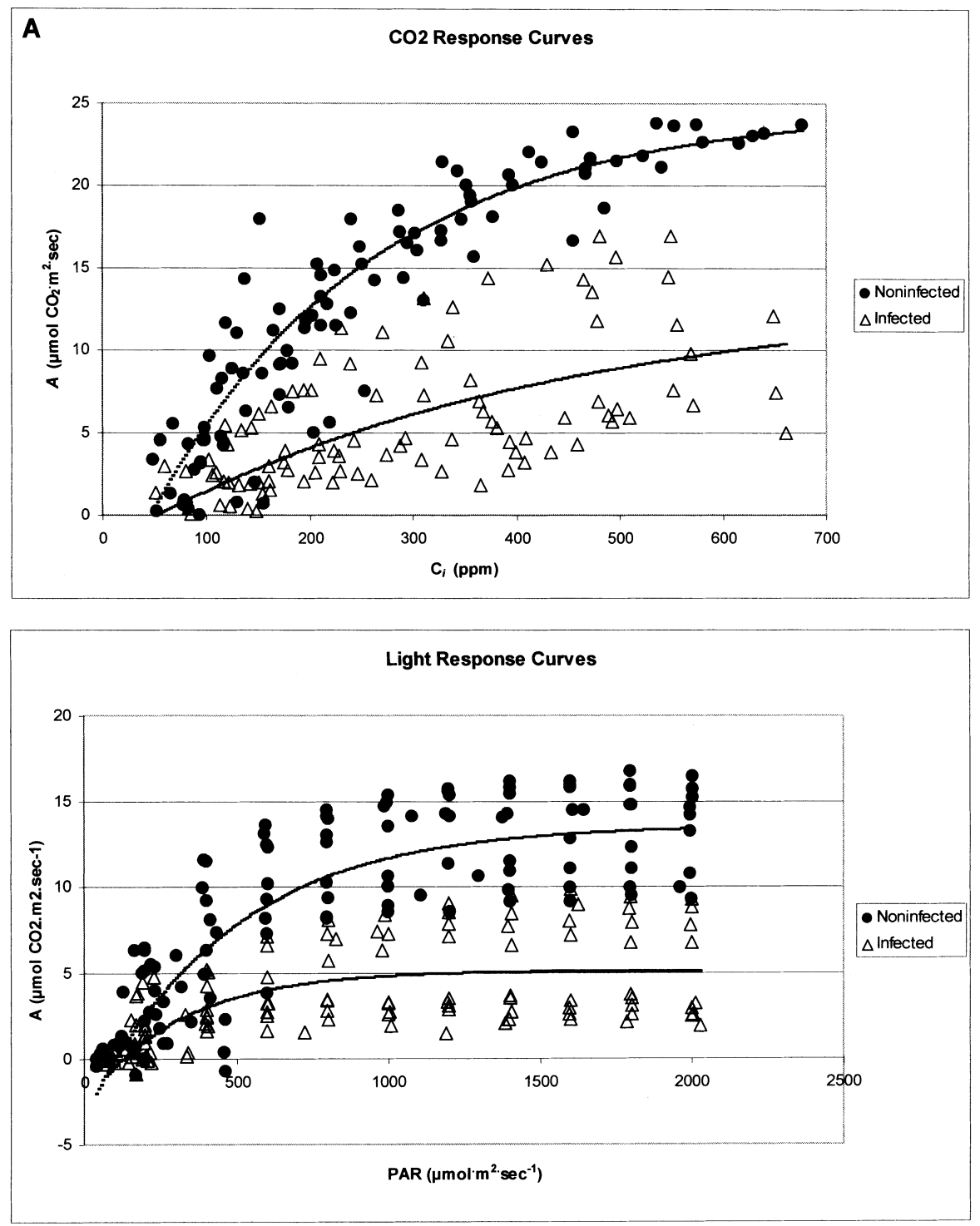

Fig. 1. $\mathrm{CO}_{2}(\mathbf{A})$ and light $(\mathbf{B})$ response curves of single leaves of potted Chardonnay grapevines infected or not infected with grape powdery mildew. 
Table 1. Effects of infection by grape powdery mildew on $\mathrm{CO}_{2}$ compensation point $(\Gamma)$, carboxylation efficiency $(k), \mathrm{CO}_{2}$ assimilation $\left(A_{360}\right)$, stomatal conductance $\left(g_{\mathrm{s} 360}\right)$, and internal $\mathrm{CO}_{2}$ concentration $\left(\mathrm{C}_{i 360}\right)$ under ambient $\mathrm{CO}_{2}, A_{\max }$ at $>900 \mathrm{ppm} \mathrm{CO}$, and stomatal limitations to $A\left(1_{\mathrm{g}}\right)$ on most recently fully expanded grape leaves on potted Chardonnay grapevines.

\begin{tabular}{|c|c|c|c|c|c|c|c|}
\hline Leaves & $\begin{array}{c}\Gamma \\
(\mu \mathrm{mol} \mathrm{CO} / \mathrm{mol})\end{array}$ & $\begin{array}{c}\mathrm{k} \\
\left(\mathrm{mol} \mathrm{CO}_{2} / \mathrm{m}^{2} / \mathrm{s}\right)\end{array}$ & $\begin{array}{c}A_{360} \\
\left(\mu \mathrm{mol} \mathrm{CO} / \mathrm{m}^{2} / \mathrm{s}\right)\end{array}$ & $\begin{array}{c}\mathrm{g}_{\mathrm{s}_{360}} \\
(\mu \mathrm{mol} \mathrm{CO} / \mathrm{mol})\end{array}$ & $\begin{array}{c}\mathrm{Ci}_{360} \\
(\mu \mathrm{mol} \mathrm{CO} \\
\left.\mathrm{CO}_{2} / \mathrm{m}^{2} / \mathrm{s}\right)\end{array}$ & $\underset{(\mu \mathrm{mol} \mathrm{CO}}{\left.\mathrm{A}_{\max } / \mathrm{mol}\right)}$ & $\left(\begin{array}{l}l_{g} \\
(\%)\end{array}\right.$ \\
\hline Noninfected & 53.7 & $0.101 \mathrm{a}$ & $10.8 \mathrm{a}$ & $113 \mathrm{a}$ & 176 & $21.9 \mathrm{a}$ & $39.4 \mathrm{~b}$ \\
\hline
\end{tabular}

${ }^{\circ} \mathrm{C}$ for $\geq 2$ weeks, and dry weights (biomass)

Statistical analysis. Statistical analysis was performed using SAS statistical software (version 8.2; SAS Institute Inc., Cary, N.C.). Curve fitting for nonlinear regression was performed using SigmaPlot software (version 8.01; SPSS Ltd., Chicago, Ill.).

\section{Results}

Light and $\mathrm{CO}_{2}$ response curves are shown in Fig. 1. While $A$ and $g_{\text {s }}$ were negatively affected by GPM infection under ambient $\mathrm{CO}_{2}$ and saturating light conditions, there was no negative effect of GPM on $\mathrm{C}_{i}$ (Table 1). Values for $A_{360}$ and $g_{\mathrm{s} 360}$ on infected plants were were determined.

$38 \%$ and $36 \%$ of those of noninfected plants. Carboxylation efficiency and $A_{\max }$ were also negatively affected by GPM infection $(37 \%$ and $47 \%$, respectively, on infected compared to noninfected plants). There was no significant difference in $\Gamma$ between treatments. Stomatal limitation to $A$ was higher in infected plants compared to noninfected plants. There was no decline in $A$ at high $\mathrm{CO}_{2}$ levels.

Single leaf measurements showed a strong relationship between $A$ and $g_{\mathrm{s}}$ on both infected and noninfected plants, as shown in Fig. 2, although the linear relationships between $A$ and $g_{\mathrm{s}}$ were different for the two treatments. There was a negative correlation between $A$ and $\mathrm{C}_{i}$ in infected plants; the relationship between $A$ and $\mathrm{C}_{i}$ in noninfected plants was not significant at
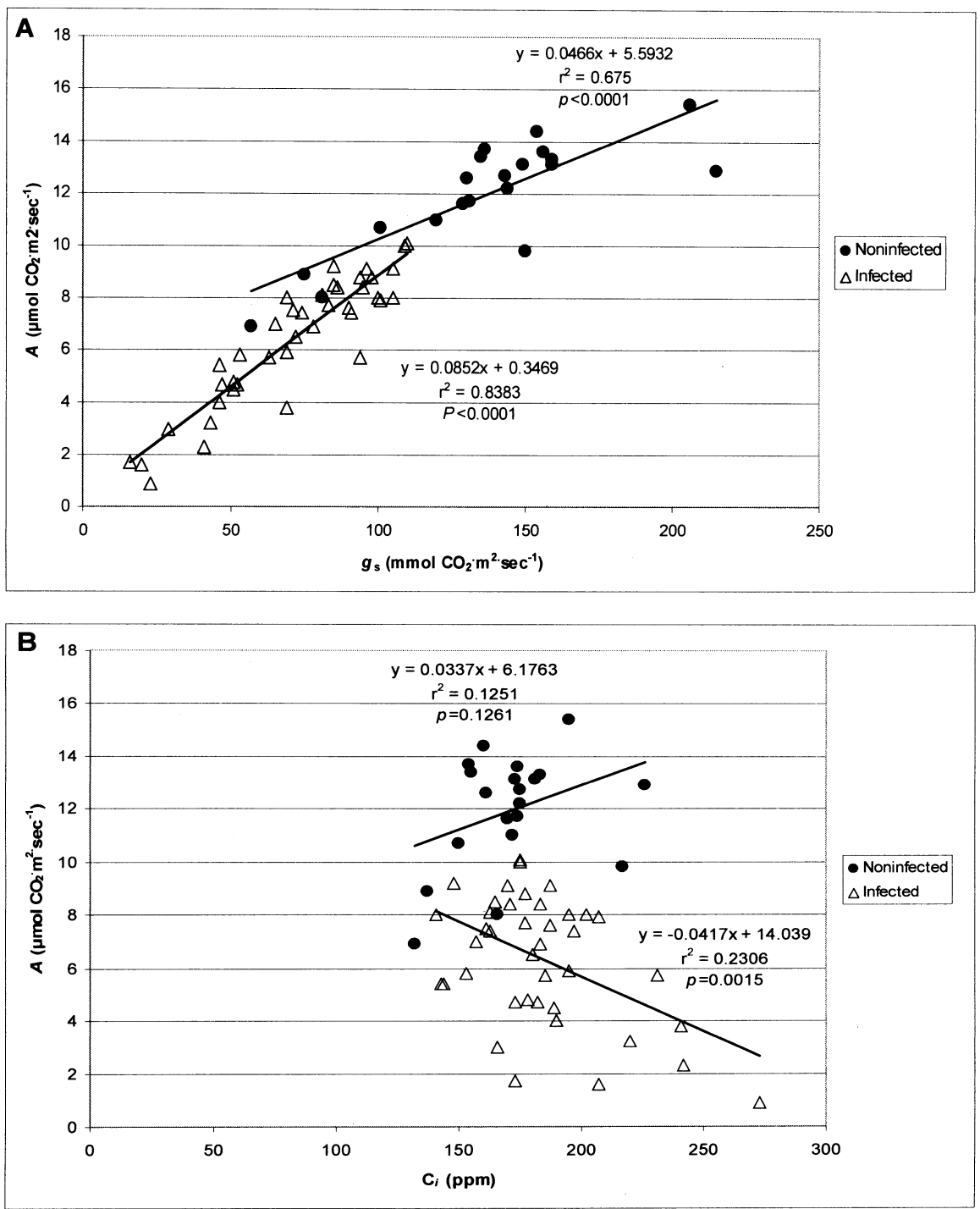

Fig 2. Relationships between single leaf $\mathrm{CO}_{2}$ assimilation $(A)$ and stomatal conductance $\left(g_{\mathrm{s}}\right)(\mathbf{A})$, and single leaf $A$ and internal $\mathrm{CO}_{2}$ concentration $\left({ }^{2}\right)(\mathbf{B})$ in leaves of potted Chardonnay grapevines infected or not infected with grape powdery mildew.
$P \leq 0.10$, but was generally positive.

Infected plants showed reduced $(52 \%) \phi$ compared to noninfected plants (Table 2). There were no differences in $\mathrm{cp}$ between treatments. There was no significant difference in chlorophyll fluorescence between treatments; $F_{v} / F_{m}=0.723$ for infected plants vs. 0.742 for noninfected plants $(p=0.4268)$. There were no also no differences in $\mathrm{F}_{\mathrm{v}} / \mathrm{F}_{\mathrm{m}}$ between different levels of disease severity (data not shown).

There were no consistent patterns of single leaf responses to variable levels of GPM infection on leaves of infected plants; although there were differences in $A_{360}$ among disease severity levels (data not shown), there was no correlation between disease severity and $A_{360}$ and other response curve parameters. No differences in cane length were observed betweein infected and noninfected vines. Infected vines had $79 \%$ of the total biomass, as determined by dry weight, of the noninfected plants at the end of the season (data not shown, $p=0.0012$ ).

\section{Discussion}

GPM infection compromised the $\mathrm{C}$ assimilation mechanism of grape leaves at several levels. The reduced $k$ values for infected plants indicate that the carboxylation reactions, on a leaf area basis, were negatively affected by GPM infection. Similarly, reductions in $\phi$ in infected plants indicate a reduction in overall quantum efficiency on a leaf area basis. These data are consistent with those of Lakso et al. (1982), who found that GPM damaged the photosynthetic apparatus of grape leaves by causing death of palisade cells. The lack of differences in chlorophyll fluorescence between treatments indicates that there was no significant effect of GPM infection on the specific PSII thylakoid reactions, and that the reduction of $A$ as a consequence of GPM infection was not due to disruptions of specific biochemical pathways, but rather to relatively large-scale destruction of entire cells. GPM fungi do not actually invade palisade cells, only epidermal cells (Pearson and Goheen, 1988). However, the death of adjacent palisade cells has been consistently noted (Doster and Schnathorst, 1985; Lakso et al., 1982), presumably due to a hypersensitive response similar to that observed on fruit (R.C. Seem, personal com-

Table 2. Effects of infection by grape powdery mildew on photochemical efficiency $(\phi)$, and light compensation point $(\mathrm{cp})$ on most recently fully expanded grape leaves on potted Chardonnay grapevines.

\begin{tabular}{|c|c|c|}
\hline & $\begin{array}{c}\phi \\
(\mu \mathrm{mol} \mathrm{CO} / \mathrm{mol} \mathrm{PPF})\end{array}$ & $\begin{array}{c}\mathrm{cp} \\
\left(\mu \mathrm{mol} \mathrm{CO} / \mathrm{m}^{2} / \mathrm{s}\right)\end{array}$ \\
\hline Infected & $0.02 \mathrm{~b}$ & 90 \\
\hline Noninfected & $0.04 \mathrm{a}$ & 95 \\
\hline$P$ & 0.0008 & 0.8216 \\
\hline
\end{tabular}


munication), and the results of this experiment are consistent with photosynthetic losses as a consequence of palisade cell destruction.

The positive association between $g_{\mathrm{s}}$ and $A$ in leaves of both infected and noninfected plants indicates a strong mechanistic relationship between the two, and that the correlation of $g_{s}$ on $A$ is stronger in leaves of infected plants than in leaves of noninfected plants. This stronger relationship is reflected in the negative relationship between $A$ and $\mathrm{C}_{i}$ in infected leaves. The relationship between $A$ and $\mathrm{C}_{i}$ was much weaker, but positive, in noninfected leaves. The correlation between increased $g_{\mathrm{s}}$ and $A$ is similar to that observed in defoliation experiments on grapevines, when remaining leaves demonstrated photosynthetic compensation for reduced leaf area (Candolfi-Vasconcelos and Koblet, 1991; Hofäcker, 1978; Petrie et al., 2000). Photosynthetic compensation has also been demonstrated in the case of powdery mildew infection of pea (Ayers 1981). Results from a contemporary study on both single leaves and whole vines were inconclusive regarding photosynthetic compensation in grapevines (Nail and Howell, 2003); some experiments suggested that grapevines might compensate for GPM severity as great as $20 \%$, while others indicated than any severity of GPM could inhibit $A$. However, in this experiment, any possible photosynthetic compensation was apparently overridden by the negative effects of the high levels of GPM infection, as $A$ levels on leaves of infected plants were consistently lower than those of leaves of noninfected plants. The lack of compensation was also evident in the reduced $k$ and $\phi$ of infected plants; previous studies of photosynthetic compensation for reduction in leaf area on sour cherry showed that $k$ and, to a lesser extent, $\phi$ increased after partial (20\%) defoliation (Layne and Flore, 1992). Disease severity in this experiment was much higher than $20 \%$.

Increased $l_{g}$ in infected leaves also shows stomatal influences on $A$, and implies that the stronger positive relationship between $g_{\mathrm{s}}$ and $A$ on infected leaves might be partially alleviated by increased stomatal resistance. The lack of decrease in $A$ at saturating PAR for either infected or noninfected plants indicates that ribulose-1,5-bisphosphate (RuBP) regeneration capacity is not affected by GPM infection.

Results from these experiments are consistent with those to be expected from necrosis of palisade cells, with which GPM has been associated (Lakso et al., 1982), but not by interfering with specific metabolic $\mathrm{CO}_{2}$ assimilation pathways. The reduction in carboxylation efficiency was similar to that observed in winter wheat infected with powdery mildew (Rabbinge et al., 1985). The reduced electron transport in response to powdery mildew of barley (Holloway et al., 1992), attributed to the destruction of chloroplasts and not inhibition of metabolic pathways, also resembled the results of this study. Powdery mildew of sugar beets did alter metabolic pathways by reducing enzyme activity (Magyarosy et al., 1976), indicating that the mechanisms of inhibition of the photosynthetic apparatus vary with the obligate pathogen and/or host-plant reaction.
Results from these experiments suggest that GPM inhibits single leaf $A$ in grapevines by quantitatively interfering with the carbon assimilation apparatus of individual leaves. These reductions in $A$ are caused mostly by disruptions of stomatal and photochemical functions. Cultural practices designed to reduce GPM infection in vineyards may have both short- and long-term health benefits for grapevines as a result of a lack of GPM-induced reduction of $A$. Additional research should address the impact of lower levels of GPM on the photosynthetic apparatus of individual leaves and whole vines.

\section{Literature Cited}

Ayers, P.G. 1981. Powdery mildew stimulates photosynthesis in uninfected leaves of pea plants. Phytopathologische Zeitschrift 100:312-318.

Boote, K.J., J.W. Jones, J.W. Mishoe, and R.D. Berger 1983. Coupling pest to crop growth simulators to predict yield reductions. Phytopathology 73:1581-1587.

Boucher, T.J., D. G. Pfeiffer, J.A. Barden, and J.M Williams. 1987. Effects of simulated insect injury on net photosynthesis of potted grapevines. HortScience 22:927-928.

Buwalda, J.G. and G. Noga. 1994. Intra-plant differences in leaf chlorophyll fluorescence parameters in perennial fruiting plants. N.Z. J. Crop Hort. Sci. 22:373-380.

Candolfi-Vasconcelos, M.C. and W. Koblet. 1990. Yield, fruit quality, bud fertility and starch reserves of the wood as a function of leaf removal in Vitis vinifera-Evidence of compensation and stress recovering. Vitis 29:199-221.

Candolfi-Vasconcelos, M.C. and W. Koblet. 1991. Influence of partial defoliation on gas exchange parameters and chlorophyll content of field-grown grapevines. Mechanisms and limitations of the compensation capacity. Vitis 30:129-141.

Candolfi-Vasconcelos, M.C., W. Koblet, G.S. Howell, and W. Zweifel. 1994. Influence of defoliation, rootstock, training system, and leaf position on gas exchange of Pinot noir grapevines. Amer. J. Enol. Viticult. 45:173-180.

Chellemi, D.O. and J.J. Marois. 1992. Influence of leaf removal, fungicide applications, and fruit maturity on incidence and severity of grape powdery mildew. Amer. J. Enol. Viticult. 43:53-57.

Dorster, M.A. and W.C. Schnathorst. 1985. Comparative susceptibility of various grapevine cultivars to the powdery mildew fungus Uncinula necator. Amer. J. Enol. Viticult. 36:101.

Downton, W.J.S., W.J.R. Grant, and B.R. Loveys. 1987. Diurnal changes in the photosynthesis of field-grown grape vines. New Phytol. 105:71-80.

Flore, J.A. and C. Irwin. 1983. The influence of defoliation and leaf injury on leaf photosynthetic rate, diffusive resistance, and whole tree dry matter accumulation in apple. HortScience 18:72 (abstr.).

Flore, J.A. and A.N. Lakso. 1989. Environmental and physiological regulation of photosynthesis in fruit crops, p. 111-157. In: J. Janick (ed.). Horticultural reviews. vol. 2. Timber Press, Portland, Ore.

Gadoury, D.M., R.C. Seem, R.C. Pearson, W.F. Wilcox, and R.M. Dunst. 2001. Effects of powdery mildew on vine growth, yield, and quality of Concord grapes. Plant Dis. 85:137-140.

Goodman, R.N., Z. Kiraly, and K.R. Wood. 1986. Photosynthesis, p. 46-74. In: R.N. Goodman, (ed.). The biochemistry and physiology of plant diseases. Univ. Mo. Press, Columbia.

Hofäcker, W. 1978. Investigations on the photo- synthesis of vines. Influence of defoliation, topping, girdling and removal of the grapes. Vitis 17:10-22.

Holloway, P.J., D.J. Maclean, and K.J. Scott. 1992. Electron transport in thylakoids isolated from barley leaves infected by the powdery mildew fungus (Erysiphe graminis DC. Ex Merat f.sp. hordei Marchal). New Phytol. 120:145-151.

Intrieri, C., S. Poni, B. Rebucci, and E. Magnanini. 1997. Effects of canopy manipulations on wholevine photosynthesis: Results from pot and field experiments. Vitis 36:167-173.

Johnson, K.B. 1987. Defoliation, disease, and growth; A reply. Phytopathology 77:1495-1497.

Jones, H.G. 1985. Partitioning stomatal and nonstomatal limitation to photosynthesis. Plant Cell Environ. 8:95-104.

Krause, G.H. and E. Weis. 1991. Chlorophyll fluorescence and photosynthesis; The basics. Annu. Rev. Plant Physiol. Plant Mol. Biol. 42:313-349.

Lakso, A.M., C. Pratt, R.C. Pearson, R.M. Pool, and M.J. Welser. 1982. Photosynthesis, transpiration, and water use efficiency of mature grape leaves infected with Uncinula necator (powdery mildew). Phytopathology 72:232-236.

Layne, D.R. and J.A. Flore. 1992. Photosynthetic compensation to partial leaf area reduction in sour cherry. J. Amer. Soc. Hort. Sci. 117:279-286.

Layne, D.R. and J.A. Flore. 1993. Physiological responses of Prunus cerasus to whole-plant source manipulation. Leaf gas exchange, chlorophyll fluorescence, water relations and carbohydrate concentrations. Physiologia Plantarium 88:44-51.

Layne, D.R. and J.A. Flore. 1995. End-product inhibition of photosynthesis in Prunus cerasus L. in response to whole-plant source-sink manipulation. J. Amer. Soc. Hort. Sci. 120:583-599.

Magyarosy, A.C., P.Schürmann, and B.B. Buchanan. 1976. Effect of powdery mildew infection on photosynthesis by leaves and chloroplasts of sugar beets. Plant Physiol. 57:486-489.

Marquardt, D.W. 1963. An algorithm for least squares estimation of parameters. J. Soc. Ind. Appl. Math. 11:431-441.

Nail, W.R. and G.S. Howell. 2003. Effects of powdery mildew infection on carbon assimilation of potted chardonnay (Vitis vinifera L.) grapevines. (in press).

Ough, C.S. and H.W. Berg. 1979. Powdery mildew sensory effect on wine. Amer. J. Enol. Viticult. 30:321.

Pearson, R.C. and A.C. Goheen. 1988. Compendium of grape diseases, APS Press St. Paul, Minn.

Petrie, P.R., M.C.T. Trought, and G.S. Howell. 2000. Influence of leaf ageing, leaf area and crop load on photosynthesis, stomatal conductance and senescence of grapevine (Vitis vinifera L. cv. Pinot noir) leaves. Vitis 39:31-36.

Pool. R.M., R.C. Pearson, M.J. Welser, A.N. Lakso, and R.C. Seem. 1984. Influence of powdery mildew on yield and growth of Rosette grapevines. Plant Dis. 68:590-593.

Poston, F.L., L.P. Pedigo, R.B. Pearce, and R.B. Hammond. 1976. Effects of artificial and insect defoliation on soybean net photosynthesis. J. Econ. Entomol. 69:109-112.

Rabbinge, R., I.T.M. Jorritsma, and J. Schans. 1985. Damage components of powdery mildew in winter wheat. Neth. J. Plant Pathol. 91:235-247.

Shtienberg, D. 1992. Effects of foliar diseases on gas exchange processes: A comparative study. Phytopathology 82:760-765.

Stacey, D.L. 1983. The effect of artificial defoliation on the yield of tomato plants and its relevance to pest damage. J. Hort. Sci. 58:117-120.

Yarwood, C.E. 1967. Responses to parasites. Annu. Rev. Plant Physiol. 18:419-438. 